\title{
Charting Ahead: Navigating Threats and Challenges to the Urban-Serving Research University Mission
}

Desiree D. Zerquera, Ph.D., and Erin Doran, Ed.D.

\begin{abstract}
The higher education context that our CUMU institutions must navigate is complex and begets challenges resulting from the distinct mission our institutions seek to uphold. The implications of these challenges give rise to impacts on everyone within the institution and consequently our constituents within the cities we seek to serve. Bringing together literature, emerging research, and points from discussions at the 2016 CUMU conference, this paper analyzes challenges and their implications and highlights the strategies being employed to navigate them. We consider the tensions inherent in the urban-serving university's identity, the cost of serving urban regions, and the state structures that provide funding. All of these tensions have implications for commitment to mission, access for historically marginalized students, and the experiences of faculty within the institution. We also discuss strategic initiatives and efforts that reflect collaboration, strategic alignment, and innovation. This work is of value for those working within urban-serving universities, those who work to uphold their mission in higher education, and policy makers that shape the context of these institutions' work.
\end{abstract}

\section{Keywords}

Mission management, strategic efforts, policy context

\section{Introduction}

Urban-Serving Research Universities (USRUs) play an important role within our nation's cities and the achievement of educational and societal opportunities for our urban regions and inhabitants (Zerquera, 2016). However, pressures from the broader environment present challenges to this mission, often to achieve more with less resources, or to take on new missions that fundamentally change the target student populations of an institution and its constituents. Current pressures threaten the ability of these institutions to achieve a balance between providing access, especially to historically underserved student populations, and the types of external pressures that realign institutional priorities. These pressures include: (a) mission differentiation efforts; (b) resource competition; (c) performance-based funding criteria; (d) prestige expectations; and (e) faculty pressures to focus more on research than teaching and service. More is needed to better understand how our institutions are experiencing and navigating these pressures.

Drawing from literature, emerging research, and discussions among Coalition for Urban and Metropolitan Universities (CUMU) members at the 2016 CUMU conference, this paper seeks to explore current tensions on the mission of USRUs. The purpose of this work is to explain some 
of the ways these tensions have played out in institutions and policies around the country and to provide some of the individual and collaborative responses USRUs have made in negotiating or reframing these tensions in service of their mission. Lessons learned from these strategies and recommendations for how to chart ahead within this context are posed to challenge USRUs to think creatively and strategically for the betterment of our cities and the students we serve.

\section{Situating the Mission of Urban-Serving Research Universities}

USRUs serve their urban regions in a number of ways, with a key part of the USRU mission to provide access to higher education for residents of its surrounding regions (Barlow, 1988; Grobman, 1988; Hathaway, Mulhollan, \& White, 1990). In so doing, USRUs play an important role in upholding the American dedication to providing educational opportunity (Diner, 2012; Elliott, 1994; Rhatigan \& Kelley, 1990). Research within the context of USRUs typically involves a distinct process and approach to research that includes working with different constituencies to identify, define and solve urban problems through engaged research with their surrounding communities (Barlow, 1998; Soo, 2010). They contribute to the local economy by providing training in professional fields needed for the success of their region in a context that interweaves theory and practice (Harcleroad \& Ostar, 1987; Mulhollan, 1990). Additionally, they contribute to solving the city's problems by serving as a model institutional citizen within the city, centering concerns on urban issues, and acting as a center of political, economic, and cultural advancement (Barlow, 1998; van der Wusten, 1998).

Many USRUs were founded during the mid-twentieth century, in response to urbanization, mass migration to urban areas, and the increased demand for higher education in the post-World War II era (Grobman, 1988; Harcleroad \& Ostar, 1987; van der Wusten, 1998). Grobman (1988) develops a taxonomy of urban institutions based on their shared histories of founding, identifying two main types. The first set of institutions comprise what he calls secondary urban universities, which were institutions that long existed in metropolitan regions as either private institutions, seminaries, or teacher's colleges and were converted into public, urban-serving institutions to provide access and develop their growing regions. Examples include the University of Louisville, a former seminary in the primary urban center of Kentucky; the University of Toledo, a former private arts and trades school in northern Ohio; and the University of WisconsinMilwaukee and the University of Texas at El Paso, which were former normal schools devoted to teacher training. These institutions differ in their histories from those Grobman identifies as primary urban state universities, which were established as new campuses where the conversion of a pre-existing campus was not possible or were created by combining disparate extension campus efforts from a remote state university to become one institution. Examples of these institutions include Indiana University-Purdue University Indianapolis, the University of Illinois at Chicago, the University of Texas at San Antonio, and the University of South Florida.

Though these two groups of institutions differ in the conditions surrounding their founding, they share a common history of being established - or appropriated — out of a need by states to serve their growing metropolitan regions and meet increasing demands for access to higher education (Grobman, 1988; Harcleroad \& Ostar, 1987; van der Wusten, 1998). As such, these institutions are distinct from many state colleges and the land-grant institutions "established as pastoral 
retreats, as part of a general social hostility towards the city and its corruption" or universities established in urban areas that "more often than not were walled institutions within which an attempt was made to create a haven from the urban environment" (Barlow, 1998, p.149).

Thus, the USRU mission centers these institutions as being citizens of the cities they inhabit, providing access to higher education, and working with members in the city to identify and address social problems (Zerquera, 2016). This mission rings true today, as demonstrated by CUMU, which among other aims seeks to support the fulfillment of this mission within our nation's urban institutions. These foundational values are also evidenced within USRU institutional missions. For instance, the University of Texas at El Paso (UTEP) has as part of its mission to fulfill the "role as an intellectual, cultural and socioeconomic asset to the region, offering programs to meet human resource needs and contribute to the quality of life" (UTEP, n.d.). Further, the institution boasts that it "is committed to providing access and opportunity to the people of the El Paso region and the State of Texas" (UTEP, n.d.).

However, this mission is wrought with inherent challenges and tensions. Particularly within today's higher education context, the awareness of these tensions, their implications, and how to navigate them, are essential for the continued enactment of the urban-serving mission.

\section{Key Areas of Tension on the USRU Mission}

Being committed to achieving the tripartite mission of higher education - teaching, research, and service - in ways that serve the surrounding city is a tremendous endeavor. This mission is filled with inherent tensions that are exacerbated by current policy discourse. We discuss three key areas where these tensions play out: the urban-serving identity, costs of serving an urban mission, and metrics systems misaligned with USRU work.

Identity within a Juxtaposed Space

The urban-serving philosophy of USRUs has created several conflicts for these institutions. The association with the urban context brings about connotations and association (Elliot, 1994), invoking "images of crime, squalor, [and] underprepared diverse students" (Severino, 1996, p.292), that colleges and universities may try to reject. Recasting urban institutions as metropolitan can be seen as evidence of an effort to disassociate with this connotation (Severino, 1996). Further, while the Carnegie Classification's elective component of community engagement begins to speak to the distinct mission of USRUs, these institutions are not perfectly captured within the Carnegie system of classification. This absence only contributes to the already tenuous situating of USRUs.

Additionally, rhetoric surrounding the USRU movement has focused on comparing USRUs to land-grant institutions, a comparison and has been important in the development of USRU identity (Severino, 1996). The ongoing investment and veneration of the land-grant colleges to the point of making them the prototype of public higher education has served to perpetuate the agrarian myth of higher education - a belief in the pastoral setting as being the ideal environment for college learning (Rudolph, 1990; Thelin, 2004). This has contributed to an ongoing dilemma 
for USRUs: with higher education's “persistent fixation on the pastoral model, the urban university has always had difficulty being accepted as 'the real thing"' (Thelin, 1990, p.xv). Thus, this has contributed to the "shaping [of] an institutional identity within a juxtaposed space rather than a reclaimed and distinguished one" (Zerquera, 2016, para. 26). In turn, USRUs are seen as less than, a perspective shared by potential students and state policymakers alike. Thus, the identity of USRUs has been continuously challenged, imposing tensions resulting from evaluating these institutions by what they are not instead of what they are.

\section{Cost of the Urban Mission}

Further, the problems that USRUs aim to address through their service and research are large, difficult, and expensive (Carnegie Commission on Higher Education, 1972; Cisneros, 1995; Martinez \& Brawley, 2003; van der Wusten, 1998). Serving an access mission is costly. Students from historically marginalized backgrounds tend to face inequities in the K-12 system, with structural barriers for students in schools that typically serve large proportions of students of color (Hanushek, 1989; Kahlenberg, 2000; Noguera, 2003; Teranishi, Allen, \& Solorzano, 2004; Yosso, 2005).

The institutions of higher education that seek to serve these students then inherit the inequity passed on by the K-12 system (Wagner, 1990; Venegas, 2011). With expansion of the collegegoing population, increasingly, more and more students attend college who not only bring with them this K-12 background, but a host of various other intersecting barriers not always accounted for, such as low-income status, demands outside of school for work and family, and misalignment with the norms and structures within the college-going process (Meyers, Berling, \& Corcoran, 2012; Venegas, 2011). Serving these students requires institutions to be introspective and provide extensive services that support them to success. Many institutions embrace this challenge, creating rich relationships with their urban communities and benefitting them in the process (Englert, 1997; Maurrasse, 2001). CUMU institutions highlight, for instance, the use of extended education and outreach programs, which seek to ameliorate some of the challenges within K-12, foster stronger K-16 partnerships, and enhance not just access but success of historically underserved populations (Moore, 2013; Perna, 2011; Perry, 2011; Rousseau, 2007). Still, the challenge is ever present. The complexity of these problems may beget political difficulties, and particularly within evaluative structures.

Performance- and Prestige-Based Funding

As discussed in the context of school equity previously, funding is a perennial challenge in higher education, and multiple scholars have noted that nationally, funding for higher education has fallen (Dowd \& Shieh, 2013) and has no prospect of returning to previous levels (State Higher Education Executive Officers, 2014). National priorities that emphasize accountability with regards to student completion rates are positioned in conflict with the growing diversity of the college-going population (Allen \& Allen, 2003; Astin \& Oseguera, 2004; Kallison \& Cohen, 2010).

At the same time, the use of performance-based funding is rising (Fain, 2014) with some 30 states that currently use some type of performance-based funding in higher education with 
another four that are in process of adding that formula funding to their state budgets (National Conference of State Legislatures, 2015). Previous iterations of such funding provided bonus funding to states while current performance funding is tied to the base funding that states allocate to its institutions (Lahr et al., 2014). For institutions like USRUs, performance measures may be misaligned with mission, especially when outcomes are the sole measure and certain inputs, like teaching and advising, are cast aside (Dowd \& Shieh, 2013).

Performance funding is not the only state structure that impacts USRUs. Several states have adapted hierarchical evaluations of their state's public universities, with financial rewards attached for those within higher tiers. For instance, in 2009, the Texas Legislature passed H.B. 51, a plan to incentivize public universities to strive toward Tier One status by creating grants for such activities such as hiring research-oriented faculty, including endowed professorships (H.B. 51, 2009). The Legislature noted that Texas had only three Research 1 (R1) institutions at the time and argued that the establishment of more R1 institutions could positively impact the state's economic growth with more institutions that achieved the "Highest Research Activity" designation from the Carnegie Classification. Similarly, the state of Florida recently adapted SB 1076 in 2013 and supplemented it this past year, which established metrics to evaluate the level of preeminence among its institutions (Kumar, 2013). Gaining this status enables institutions to be eligible for additional funding to support research engagements. Earning such label requires institutions to meet a number of metrics set out by the state, which include size of endowment, graduation and retention rate, and incoming student grade point average and SAT scores.

Another resource stream, the attraction of gaining such status must surely be appealing to institutions struggling to survive within the state's financial context. However, the metrics evaluate activity that is somewhat disassociated from the USRU mission. For instance, the research that is most recognized and supported within this lens is typically not practitionerdriven and engaged with community partners. Similarly, the SAT has been noted to be biased towards students of color and institutions that serve them are penalized in ranking systems that consider it (Freedle, 2003). The observed and potential implications of these structures and the other tensions described are discussed at length in the following section.

\section{Implications of Tensions on USRUs}

The tensions exerted on USRUs surely have consequences on how these institutions make decisions in their effort to navigate the tensions and survive within the higher education context that may at times work against what they seek to do. The impacts, alluded to in the previous section, reach far into all aspects of institutional work. For this paper, we hone in on three areas in particular where implications have been observed: academic striving, diminished access for underserved students, and pressures on the work of faculty.

\section{Academic Striving}

The act of striving in higher education institutions is defined as "the pursuit of prestige within the academic hierarchy" (O’Meara \& Bloomgarden, 2011, p. 40). This process can take on different actions including changes to admissions processes (Crisp, Horn, Dizinno, \& Wang, 2010; 
O’Meara, 2007), how resources are allocated (Morphew \& Baker, 2004; O’Meara, 2007), and changes in mission (Gonzales, 2013). Striving has also been attributed to the attitudes and values of faculty, many of whom are trained within pastoral, research-intensive institutions and bring the norms and expectations of that campus setting to their new urban campuses that have different values around the meaning of their work (Morphew, 2000; Rhoades, Kiyama, McCormick, \& Quiroz, 2009; Walzer, 2010).

Striving, especially in institution that were previously broad access or teaching institutions, fundamentally changes the focus of the institution, usually toward research and selectivity (O'Meara, 2007; O'Meara \& Bloomgarden, 2011). As such, the active pursuit of prestige can be disruptive to various parties within the institution. It can have impacts on faculty attitudes around their work, conceptions of their identity as academics, and their work-life balance (Gonzales, 2013; O’Meara \& Bloomgarden, 2011). Some research has extended similar impacts to the experiences of graduate students within these institutions as well (Gardner, 2010).

While striving is often internally driven, the context of the higher education environment may introduce conditions that contribute to prestige-seeking behavior. Because of their mission and tensions described above, USRUs have been noted to be susceptible to the value systems of research-intensive and more highly selective universities (Lynton \& Elman, 1987; Mulhollan, 1990) which differ in many ways from the aims USRUs seek. This may also contribute to additional implications, such as access for marginalized students and experiences of faculty within the institution.

\section{Diminished Access for Marginalized Students}

Many of the measures imposed on USRUs evaluate on the basis of the academic preparation of incoming freshmen. Performance-based funding, for instance, threatens the equity and access, especially when outcomes are the sole measure and certain inputs, like teaching and advising, are cast aside. For institutions like USRUs, these labors to serve students may often result in fruits not considered edible for these evaluative systems. The pressures to meet metrics may have inequitable impacts on students being served.

This is interconnected with a common approach employed by universities seeking to increase outcomes more quickly through increasing admissions requirements. In modeling increased admissions requirements at two Texas urban striving institutions, Crisp and colleagues (2010) found that traditionally underserved students are disproportionately impacted by changes to admissions requirements. One of the universities in the sample, the University of Texas at San Antonio (UTSA) which is also an USRU institutions, lowered its admissions rate from as high as 99\% in 2004 (Crisp, et al., 2010) to approximately 60\% less than a decade later (Chavez, 2013). In the plan that outlined these strategic changes, UTSA overtly stated its efforts to increase success rates by excluding students previously served by their institution and whom they described as being less likely to succeed.

As a result of the increased admissions requirements at UTSA from 2013 onward and changes to the state developmental education plan (Texas Higher Education Coordinating Board, 2012), the university did away with certain developmental courses, specifically the lowest-level 
developmental reading course because students who tested at that level no longer qualified for admission to the university. Should more USRUs follow this practice, more students of color who are overrepresented in developmental education (Bahr, 2010) related to high proportions of disservice in the K-12 sector (Gandára \& Contreras, 2009; Strayhorn, 2016) will be shut out of higher education opportunity at USRU institutions.

\section{Faculty Pressures}

These tensions have implications for the work of faculty within USRUs as well. As previously noted, while faculty themselves can play a role in striving within the institution, these pressures also become imposed on the work of faculty. Certain emphases, such as those which might bring about preeminence at the state level, tends to push faculty work and resource allocation toward a greater focus on research and grant development (Morphew \& Baker, 2004; O’Meara, 2007). An increased focus on these aspects of faculty work tend to take away time from other parts of academic life, including service and community-engaged work.

Scholarship in the Metropolitan Universities Journal has spoken to the importance of community-engaged research and service and the special place that urban institutions have to exchange with their localities (Siewell \& Thomas, 2015; Watson-Thompson, 2015). Work in this journal also calls for the greater recognition of the impact that this work has on communities (e.g., Watson-Thompson, 2015) and how it should be valued in tenure and merit structures for faculty (Jacquez, 2014). A diminished focus on community-engaged scholarship threatens the viability of our cities and the role of higher education in society overall.

\section{Navigating These Tensions}

Finding actionable solutions for complex issues in light of stagnant or decreasing funding is a challenge for institutions. In light of discussions at the CUMU conference and ongoing research on USRUs, the following areas were identified as examples of individual and collective institutions working around or in spite of policies that created tensions with their urban mission.

\section{Consortiums}

While organizations like CUMU and the Coalition of Urban Serving Universities (USU) reflect a shared commitment to upholding and supporting the enactment of the USRU mission, institution-driven regional consortiums throughout the country have also been formed. While foregrounding different aims, these consortiums act to pool resources and influence from their states and maintain commitment to their urban-serving missions. For instance, the Consortium of Universities in the Washington Metropolitan Area (CUWMA), which was formed in the 1960s, boosts access and opportunity for students in the Washington, DC area. The CUWMA harnesses the geographic proximity of different types of DC-based institutions (e.g., two-year and fouryear, public and private) to create collaborations in teaching, advocacy, and research that benefit the entire metropolitan community (Cavanaugh, 2015). Importantly too, they advocate for the value of serving the greater Washington, DC region and leveraging their shared commitment to do so. 
This spirit of aligning with other institutions in effort to better enact a shared mission is reflected in more recent consortiums emerging in Florida and California. The Florida Consortium of Metropolitan Research Universities, reflects a collaboration across three urban universities in the state. All work together to increase retention and graduation rates, lower the amount of debt carried by students, and produce graduates that will meet the demands of Florida's economy (Hodge, 2016). In its short time, among other accomplishments, the Consortium has been able to garner state and foundation funding, which is shared across institutions to support initiatives around STEM and career-readiness. Another example is provided by the CSU5, a collaboration between five California State University (CSU) campuses in the Los Angeles area for the purpose of increasing workforce training and educational attainment of students ("About CSU5," n.d.). These institutions work together to tell the CSU story as stated by a CUMU conference attendee, meet demands from the state, and collectivize to garner funding to support shared initiatives. These consortiums provide examples of collaboration around shared goals to uphold the USRU mission through collectivization.

\section{Addition of Engaged Scholarship Addendums to Tenure Packets}

As faculty are increasingly called to do work differently than before, some faculty have worked together to uphold their community-engaged focus. The intricacies of the tenure and promotion process can be difficult to navigate through a community-engaged lens. University faculty have taken it upon themselves to create innovative or supplement their institutional-wide guidelines with standards that better align with a community-engaged focus (e.g., Kirtman, Bowers, \& Hoffman, 2016).

For instance, the University of Windsor provides external reviewers a supplemental document that specifically outlines not just assessment criteria, but also provides a background framework to support the review of tenure and promotion candidates. By drawing on a strong framework, they advocate for reviewers to situate the evaluation of faculty within a community-engaged context. Loyola Marymount University has developed tenure and review guidelines that reflect a strong community-engaged focus, promoting the inclusivity of various types of scholarship. Both institutions recognize the important role of public intellectualism and publication within journals that reach practitioners and community members directly. Given the important role of faculty in shaping the tenure and promotion process, these examples demonstrate how faculty may claim of autonomy and enact creativity to ensure the support of the USRU mission through the work of scholarship.

\section{Access Approaches}

Practitioners and administrators on USRU campuses are recognizing the shift in student demographics resulting from different measures of students' qualifications. Recent research, conducted by the authors, has investigated the efforts these campuses are taking to uphold access within this challenging context. One such approach described reflects a shared investment in strengthening collaborations with area community colleges. Community colleges provide an affordable access-point into higher education for a variety of student populations, including many students of color, low-income students, and academically underprepared students for 
students who might not otherwise have the chance to pursue a postsecondary degree or credential (Cohen, Brawer, \& Kisker, 2013; Handel, 2013). Through partnerships and articulation agreements, USRUs can play an important role in boosting the degree attainment rate of their communities (Handel, 2013). While community colleges themselves play a role in preparing students for transfer, USRUs should mindfully create policies and procedures for supporting the successful transfer of students from one institution to the next in various forms, including registration, advising, financial aid, and services that help students navigate their new campus (Bahr, Toth, Thirolf, \& Massé, 2013). The stories across USRU campuses demonstrate an investment in collaboration, but the strengthening of these pipelines are essential to realizing their potential.

In addition to leveraging local community colleges, practitioners found ways of circumventing metrics and utilizing other entry points. The collection of data that determine prestige rankings (e.g., U.S. News \& World Report) and performance measures are typically based on fall firsttime in college student admissions (Ehrenberg, 2003). Thus, USRUs shared the usage of transfer admissions and spring admissions (referred to by one participant as the "access term") to uphold access points for marginalized students. The circumvention strategy demonstrates ways our campuses are working strategically to navigate pressures and remain committed to their urbanserving mission.

\section{Charting the Future: The Road Ahead}

Many of the pressures influencing change on USRUs, such as decreased funding, are unlikely to improve. Therefore, it is incumbent upon these institutions to develop ways to adapt in order to move forward in service to their missions and students. The aforementioned consortiums, especially the newer collaborations in California and Florida, may be instructive to other USRUs in the ways that multiple campuses can harness their collective strengths for advocacy, strategic planning, and in informing policies that support the USRU mission rather than threaten it. What is particularly special about these efforts are the ways in which they foster collaboration among institutions, not competition.

Relatedly, USRUs will need to think about ways they can strategically align themselves as individual campuses and as part of a network of campuses in the same urban space. Policies that prioritize certain outcomes, such as workforce preparation and training as development by the CSU5 consortium, illustrates how malleable USRUs can be in relation to changing federal and state policy discussions. Urban universities should also look among themselves to see where their interests converge and how individual contributions to a collective effort can improve the quality of education for an entire community. At the same time, USRUs should also look to redefine their roles in a community, in order to adapt responsively to changing times.

If necessity is indeed the mother of invention, the time is ripe for USRUs to innovate their practices and policies in support of a community-based mission. A starting point for leveraging the collective power of USRUs is in finding spaces to gather and exchange ideas. Organizations like CUMU, which are dedicated to the mission and sustainability of urban universities, can provide these spaces for sharing experience and ideas by strategizing conversations around the 
most pressing issues impacting this sector of higher education. Further, by facilitating partnerships with other organizations such as USU, USRUs can find a collective voice for advocacy toward the creation of policies that honor the work urban universities do in support of their locales.

\section{Conclusion}

Within today's context of increased accountability and diminished resources, the need to uphold equity is greater than ever. In this piece, we have argued that USRUs are a distinct set of universities that serve a special mission. These institutions aim to be all things to all people in their respective urban regions, having the potential to fulfill the roles critics claim have been missing from higher education institutions - a return to teaching, relationships with communities, and conducting research of relevance to real societal problems (Mundt, 1998). However, tensions in the USRU environment make fulfillment of this mission challenging at times, as their identity is not fully captured or understood, there are diminished resources for the costly work USRUs do, and performance metrics fail to appropriately capture the significant work of these institutions. The impact of these tensions are evidenced as they play out in institutions demonstrating pursuing prestige for the tangible and intangible resources it provides, diminished access for students from marginalized backgrounds, and pressures on faculty and their work. Still, there is promise as evidenced in the ways USRUs are navigating these tensions and innovating in our fight to preserve the role these universities fulfill.

The stakes for USRUs could not be higher. These institutions are "crucial to the fight to save our cities," and have potential to transform society through this type of work and be mutually benefitted by it in the process (Cisneros, 1995, p.2). Thus, risking the USRU mission jeopardizes the roles these institutions fulfill within society more generally. As institutions committed to this charge, it is important that we all collectively work together and within the current political climate to ensure that equity in educational opportunity is upheld. It requires the collaboration within and across institutions, our cities, and our nation. 


\section{References}

Allen, W.B., \& Allen, C.M. (2003). Habits of mind: Fostering access and excellence in higher education. New Brunswick, CT: Transaction Publishers.

Astin, A.W., \& Oseguera, L. (2004). The declining "equity" of American higher education. The Review of Higher Education, 27(3), 321-341. https://dx.doi.org/10.1353/rhe.2004.0001

Bahr, P.R. (2010). Preparing the underprepared: An analysis of racial disparities in postsecondary mathematics remediation. The Journal of Higher Education, 81(2), 209 237. https://dx.doi.org/10.1353/jhe.0.0086

Bahr, P.R., Toth, C., Thirolf, K., \& Massé, J.C. (2013). A review and critique of the literature on community college students' transition processes and outcomes in four-year institutions. In M.B. Paulsen (ed.), Higher education: Handbook of theory and research, 28, (459511). Dordrecht, Netherlands: Springer. https://dx.doi.org/10.1007/978-94-007-5836-0_10

Barlow, M. (1998). Developing and sustaining an urban mission: Concordia University in Montreal. In H. van der Wusten (Ed.), The Urban University and its identity: Roots, locations, roles (pp. 149-165). Norwell, MA: Kluwer Academic Publishers Group. https://dx.doi.org/10.1007/978-94-011-5184-9_11

Carnegie Commission on Higher Education (1972). The campus and the city: Maximizing assets and reducing liabilities. Hightstown, NJ: McGraw-Hill Book Company.

Cavanaugh, J.C. (2015). The Consortium of Universities of the Washington Metropolitan Area: 2015 Overview. Retrieved from https://static1.squarespace.com/static/54f72b94e4b05ca04000cf5c/t/5502ffa8e4b0bddb8d d31a40/1426259880425/Consortium+Overview+2015.pdf

Chavez, J. (2013, October 30). Enhanced admissions standards lead to UTSA's most highly qualified students. UTSA Today. Retrieved from http://utsa.edu/today/2013/10/admissions.html

Cisneros, H. G. (1995). The university and the urban challenge (Revised Edition). Rockville, MD: Department of Housing and Urban Development.

Cohen, A.M., Brawer, F.B., \& Kisker, C.B. (2013). The American community college (6th ed.). San Francisco, CA: Jossey-Bass.

Crisp, G., Horn, C., Dizinno, G., \& Wang, D. (2010). Modeling the racial and ethnic implications of admissions policy changes in the pursuit of tier one status. Journal of Diversity in Higher Education, 3(2), 71-84. https://dx.doi.org/10.1037/a0019675 
Diner, S. (2012). American urban university: An historical analysis. Metropolitan Universities Journal, 23(3), 61-77.

Dowd, A.C., \& Shieh, L.T. (2013). Community college financing: Equity, efficiency, and accountability. The NEA 2013 Almanac of Higher Education: National Education Association. Retrieved from http://cue.usc.edu/assests/Dowd_CC\%20Financing_EquEffandAccount_NEA\%20Alman ac_2013.pdf

Ehrenberg, R.G. (2003). Reaching for the brass ring: The U.S. News \& World Report rankings and competition. The Review of Higher Education, 26(2), 145-162. https://dx.doi.org/10.1353/rhe.2002.0032

Elliott, P. G. (1994). The urban campus. Phoenix, AZ: Oryx Press.

Englert, R. M. (1997). The university's role in the improvement of inner-city education. Education and Urban Society, 29(3), 373-402. https://dx.doi.org/10.1177/0013124597029003008

Fain, P. (2014, November 14). Gaming the system. Inside Higher Ed. Retrieved from https://www.insidehighered.com/news/2014/11/19/performance-based-funding-provokesconcern-among-college-administrators

Freedle, R. (2003). Correcting the SAT's ethnic and social-class bias: A method for reestimating SAT scores. Harvard Educational Review, 73(1), 1-45. https://dx.doi.org/10.17763/haer.73.1.8465k88616hn4757

Gándara, P., \& Contreras, F. (2009). The Latino education crisis: The consequences of failed school policies. Cambridge, MA: Harvard University Press.

Gardner, S.K. (2010). Keeping up with the Joneses: Socialization and culture in doctoral education at one striving institution. The Journal of Higher Education, 81(6), 658-679.

Gonzales, L.D. (2013). Faculty sense-making and mission creep: Interrogating institutional ways of knowing and doing legitimacy. The Review of Higher Education, 36(2), 179-209. https://dx.doi.org/10.1353/rhe.2013.0000

Grobman, A. B. (1988). Urban state universities: An unfinished national agenda. Little Rock, AR: River Market Books and Gifts.

Handel, S.J. (2013). The transfer moment: The pivotal partnership between community colleges and four-year institutions in securing the nation's college completion agenda. New Directions for Higher Education, 162, 5-15. https://dx.doi.org/10.1002/he.20052 
Harcleroad, F. F., \& Ostar, A. W. (1987). Colleges and universities for change: America's comprehensive public state colleges and universities. Washington, DC: American Association of State Colleges and Universities Press.

Hathaway, C. E., Mulhollan, P. E., \& White, K. E. (1990). Metropolitan universities: Models for the twenty-first century. In D. M. Johnson \& D. A. Bell (Eds.), Metropolitan universities: An emerging model in American higher education (pp.5-16). Denton, TX: University of North Texas Press.

Hodge, J. (2016, September 29). The benefits of collaboration in higher education [blog]. Retrieved from http://floridaconsortium.com/the-benefits-of-collaboration-in-highereducation/

House Bill 51, Texas 81st Legislature. (2009). Retrieved from http://www.capitol.state.tx.us/tlodocs/81R/billtext/pdf/HB00051F.pdf\#navpanes=0

Jacquez, F. (2014). Demonstrating impact as a community-engaged scholar within a research university. Metropolitan Universities Journal, 25(2), 14-26.

Retrieved from https://journals.iupui.edu/index.php/muj/article/view/20570

Kahlenberg, R.D. (2000). A nation at risk: Preserving public education as an engine for social mobility. New York: The Century Foundation Press.

Kallison, J.M., \& Cohen, P. (2010). A new compact for higher education: Funding and autonomy for reform and accountability. Innovative Higher Education, 35(1), 37-49. https://dx.doi.org/10.1007/s10755-009-9123-2

Kirtman, L., Bowers, E., \& Hoffman, J.L. (2016). Engaged scholarship: (Re)focusing on our mission. Metropolitan Universities Journal, 27(2). https://dx.doi.org/10.18060/21125

Lahr, H., Pheatt, L., Doughtery, K.J., Jones, S., Natow, R.S, \& Reddy, V. (2014). Unintended impacts of performance funding on community colleges and universities in three states [CCRC Working Paper No. 78]. Teachers College: Columbia University, Community College Research Center. Retrieved from http://ccrc.tc.columbia.edu/media/k2/attachments/unintended-impacts-performancefunding.pdf

Martinez-Brawley, E. (2003). The metropolitan mission of a research university: A study of the context and opportunities for faculty. Arizona State University: Phoenix, AZ.

Maurrasse, D. J. (2001). Beyond the campus: How colleges and universities form partnerships with their communities. New York: Routledge.

Melguizo, T. (2009). Are community colleges an alternative path for Hispanic students to attain a bachelor's degree? Teachers College Record, 111(1), 90-123. 
Meyers, D., Berling, V., \& Corcoran, K.J. (2012). Creating a new future: Recruiting and retaining nontraditional students. Metropolitan Universities Journal, 23(1), 41-58. Retrieved from https://journals.iupui.edu/index.php/muj/article/view/20503

Moore, S.D. (2013). Extended education's role: Facilitating higher education to historically underrepresented groups. Metropolitan Universities Journal, 24(2), 9-20. Retrieved from https://journals.iupui.edu/index.php/muj/article/view/20544

Morphew, C.M. (2000). Institutional diversity, program acquisition and faculty members: Examining academic drift at a new level. Higher Education Policy, 13(1), 55-77. https: dx.doi.org/10.1016/S0952-8733(99)00028-8

Morphew, C.C., \& Baker, B.D. (2004). The cost of prestige: Do new Research I universities incur higher administrative costs? The Review of Higher Education, 27(3), 365-384. https://dx.doi.org/10.1016/S0952-8733(99)00028-8

Mulhollan, P. E. (1990). Aligning missions with public expectations: The case of the metropolitan universities. In D.M. Johnson \& D.A. Bell (Eds.), Metropolitan universities: An emerging model in American higher education (pp.27-34). Denton, TX: University of North Texas Press.

National Conference of State Legislatures. (2015). Performance-based funding for higher education. Retrieved from http://www.ncsl.org/research/education/performance-funding.aspx.

Noguera, P. A. (2003). City schools and the American dream: Reclaiming the promise of public education. New York: Teachers College Press.

O’Meara, K.A. (2007). Striving for what? Exploring the pursuit of prestige. In J.C. Smart (Ed.), Higher education: Handbook of theory and research, 22 (, pp. 121-179). Dordrecht, Netherlands: Springer. https://dx.doi.org/10.1007/978-1-4020-5666-6_3

O’Meara, K.A., \& Bloomgarden, A. (2011). The pursuit of prestige: The experience of institutional striving from a faculty perspective. Journal of the Professoriate, 4(1), 39-73.

Perna, L.W. (2011). Understanding the role of research universities in improving college preparation and access at local urban high schools. Metropolitan Universities Journal, 22(3), 63-82. Retrieved from https://journals.iupui.edu/index.php/muj/article/view/20485

Rhatigan, J., \& Kelley, J. (1990). Access: A faltering commitment? Metropolitan Universities Journal, 1(2), 9-18. Retrieved from https://journals.iupui.edu/index.php/muj/article/view/19037

Rhoades, G., Kiyama, J., McCormick, R., \& Quiroz, M. (2008). Local cosmopolitans and cosmopolitan locals: New models of professionals in the academy. The Review of Higher Education, 31(2), 209-235. https://dx.doi.org/10.1353/rhe.2007.0079 
Rousseau, S. (2007). Educational reform: Toward a K-16 framework. Metropolitan Universities Journal, 18(4), 48-66. Retrieved from https://journals.iupui.edu/index.php/muj/article/view/20324

Rudolph, F. (1990). The American college and university: A history ( $2^{\text {nd }}$ Edition). Athens, GA: University of Georgia Press.

Severino, C. (1996). The idea of an urban university: A historic and rhetoric of ambivalence and ambiguity. Urban Education, 22(3), 291-313. https://dx.doi.org/10.1177/0042085996031003004

Siewell, N. \& Thomas, M. (2015). Building sustainable neighborhoods through community gardens: Enhancing residents' well-being through university-community engagement initiative. Metropolitan Universities Journal, 26(1), 173-190. Retrieved from https://journals.iupui.edu/index.php/muj/article/view/20994

Soo, D. (2010, Fall). An added dimension of mission: Metropolitan colleges and universities. Perspectives on Urban Education, 8(1), 35-40. Retrieved from https://eric.ed.gov/?id=EJ912060

Strayhorn, T.L. (2016, January 12). Factors that influence the persistence and success of Black men in urban public universities. Urban Education, 1-23. https:dx.//doi.org/10.1177/0042085915623347

Teranishi, R., Allen, W.R., \& Solorzano, D.G. (2004). Opportunity at the crossroads: Racial inequality, school segregation, and higher education in California. Teachers College Record, 106(11), 2224-2245. https://doi.org/10.1111/j.1467-9620.2004.00434.x

Texas Higher Education Coordinating Board. (2012). 2012-2017 Statewide developmental education plan: A report to the Texas legislature Senate Bill 162, $82^{\text {nd }}$ Texas legislature. Austin, TX.

Thelin, J. (1990). Rudolph rediscovered: An introductory essay by John R. Thelin. In F. Rudolph, The American college and university: A history ( $2^{\text {nd }}$ Edition) (pp. ix-xxiii). Athens, GA: University of Georgia Press.

University of Texas at El Paso (n.d.). The University of Texas at El Paso Mission. Retrieved from https://www.utep.edu/about/utep-vision-mission-and-goals.html.

van der Wusten, H. (1998). The urban university and its identity: Roots, locations, roles. Norwell, MA: Kluwer Academic Publishers. https://dx.doi.org/10.1007/978-94-0115184-9 
Venegas, K.M. (2011). Risk and shifting realities: College access and the $21^{\text {st }}$ century student. Metropolitan Universities Journal, 22(3), 5-7. Retrieved from https://journals.iupui.edu/index.php/muj/article/view/20481

Walzer, S. (2010). Crossing generational divides: Experiences of new faculty in higher education. Metropolitan Universities Journal, 21(2), 35-44. Retrieved from https://journals.iupui.edu/index.php/muj/article/view/20437

Wagner, T. (1990). Making up deficiencies: Is there a choice? Metropolitan Universities Journal, 1(2), 19-29. Retrieved from https://journals.iupui.edu/index.php/muj/article/view/19038

Watson-Thompson, J. (2015). Exploring community-engaged scholarship as an intervention to change and improve communities. Metropolitan Universities Journal, 26(1), 11-34. Retrieved from https://journals.iupui.edu/index.php/muj/article/view/20986

Yosso, T.J. (2005). Whose culture has capital?: A critical race theory discussion of community cultural wealth. Race Ethnicity and Education, 8(1), 69-91. https://dx.doi.org/10.1080/1361332052000341006

Zerquera, D. (2016). Urban-Serving Research Universities: Institutions for the public good. Higher Learning Research Communications, 6(2), https://dx.doi.org/10.18870/hlrc.v6i2.320 


\section{Author Information}

Desiree Zerquera is an Assistant Professor in the Department of Leadership Studies at the University of San Francisco. Her research examines the structuring of access and opportunity in higher education. She is particularly interested in the structuring of access within urbansering universities and draws on her experience as a student affairs practitioner, policy maker, and engaged researcher to inform her perspectives.

Desiree D. Zerquera, Ph.D. (corresponding author)

Department of Leadership Studies

University of San Francisco

2130 Fulton Ave

San Francisco, CA 94117

Email: ddzerquera@usfca.edu

Telephone: 415-422-2345

Twitter: desiree.zerquera

Erin Doran is an Assistant Professor in the Division of Higher Education at Iowa State University. Her research examines the access and experience of Latinx students in higher education and how institutions serve these students. She is particularly interested in how institutions respond to state policies and changing demographics in ways that promote culturally relevant practice at all levels of the institution from upper administration to individual classrooms.

Erin E. Doran, Ed.D.

2666A Lagomarcino Hall

School of Education-Iowa State University

901 Stange Road

Ames, IA 50010

Email: edoran@iastate.edu

Telephone: 515-294-3748

Twitter: ErinDoran_EdD 